\title{
刍议地籍测绘中的遥感测绘技术
}

\author{
巩兴光 虞雪风 \\ 浙江智谱工程技术有限公司 \\ DOI:10.32629/gmsm.v3i3.754
}

[摘 要] 随着时代的不断发展,近年来我国各行业都得到了长足的发展。尤其在进入到 21 世纪以后,在信息化技术的影响下,遥感测绘技术逐渐 在测绘工作中得到应用,相对于传统的测绘技术来说,其取得的画面更加清晰,采集的数据也更加准确。

[关键词] 地籍测绘; 遥感测绘技术; 工作原理

\section{1 遥感测绘技术在地籍测绘中应用的工作原理}

遥感测绘技术应用于地籍测绘主要是通过安装在航空仪器上的传感 器收集来自于地表的电磁波等信号, 通过信息的收集, 传送, 翻译, 成图与 解释最终对于目标地区的地表信息进行观察与分析。进行遥感测绘的初期 是对于遥感仪器获得的图像和数据进行初步的整理, 遥感仪器获得的数据 会因为各种信息失真或者不准确; 对于数据进行初步处理以后, 就要对遥 感影像进行初步的解释与校正, 利用地面的控制点进行校正; 最后是进行 遥感调查与实际调查成果进行比对。在地籍调查中对各宗地的具体位置、 权属界线、界址点和面积等进行的测量工作。由于地籍测绘是以权属调查 为先导, 并在其基础上完成的一种测量工作, 因此测量结果一经登记具 有法律效力。因为地籍测绘的特殊作用, 其测量过程具有一些固有的特 点: 第一、测量内容特殊: 一般包括地籍要素和地形要素的测量; 第二、 比例尺较大; 第三、测量结果一经登记具有法律效力; 第四、现势性: 即 测量的主要成果应该具有准确性、现势性, 如果发生变更, 则应当随时进行 变更调查和测量。

\section{2 遥感测绘技术在地籍测绘中的应用分析}

2.1 遥感测绘技术在地籍规划中的应用分析

目前中国城市面临的现状是城市密集的人口和拥堵的交通, 很多城市 地籍规划不尽合理, 所以城市的设计者希望获取城市的动态信息, 以此来 对城市进行改造。在这种情况下, 遥感测绘技术能够在一段时间内对于目 标区域进行全天候的调查, 如土地的利用情况、交通拥堵情况, 城市人口分 布密集区等, 为城市的建设提供指导。这种调查方式高效、相对经济, 在城 市规划中得到了广泛的应用。此外, 地籍测绘中遥感测绘技术还能够对于 土地的用途变更性进行调查, 得到土地目前的利用状况, 对于违法使用或 者污染性使用的土地进行及时的管理。

\section{2 遥感测绘技术在地籍图制作中的应用分析}

在计算机制图环境下应用遥感资料编制出所需的地籍图, 这是遥感信 息在地理研究和测量制图中的重要应用。利用遥感测绘技术制作地籍图的 技术流程主要体现为: 先是选择合适的影像源, 数据源不同特性也会不同, 因此提取信息的方法也不相同, 目前常用的遥感影像有Landsat-TM、SPOT 等。其次要选择某种遥感软件进行影像的几何纠正和影像的配准, 当前常 用的遥感软件有ERDAS、ENVI等。然后是遥感影像的融合, 通过影像融合, 希望不仅突出其中较高的空间分辨率, 还能保持良好的光谱特征。还可对 融合后的影像进行线性拉伸、灰度变换等增强处理, 以提高图像的对比度 和清晰度, 突出图像的细节部分, 利于影像判读和量测。最后通过目视解译
和实地踏勘相结合的方法, 把不同地物的形状和各个区域的范围从遥感影 像上提取出来, 就是形成矢量文件, 提取过程中, 地物类型可参照地籍调查 中的土地利用现状分类标准进行。

2. 3 遥感测绘技术在土地覆盖率与土地利用率监测中的应用分析

遥感测绘技术作为土地调查的一种快速而有效的技术, 在土地资源调 查, 土地利用率以及地质灾害等方面作用巨大, 这种技术具有快速、优质、 高精度、范围广、动态监测等优点, 是进行土地监测和土地管理的高效技 术手段。现如今, 我国的土地调查已然离不开遥感测绘技术的支撑, 直接利 用多时相、多源数据来寻求变化, 通过图像处理和影像判读来确定变化属 性及进行统计分析, 这样就大大减少了对无变化区域作业分类时作业人 员的工作量, 有效提高了监测精度。利用遥感测绘技术还能获取土地利 用的趋向, 在遥感图中, 可以分析出今后一段时间内土地利用的发展趋 势, 为防止乱用土地提供执法指导, 此外, 利用遥感测绘技术可以对于某 地区的植被覆盖率进行综合的检查, 防止出现面子工程, 保护可用耕地 和植被覆盖率。

2. 4 遥感测绘技术在地基动态监测中的应用分析

随着科技的进步发展, 诸多先进技术已融入地籍测绘中, 比如遥感结 合地理信息系统, 以及GPS等定位技术, 给土地测量带来了更多的方便。地 籍测绘中遥感测绘技术的应用, 最直接的一点便是其动态监测。所谓动态 监测, 就是应用遥感测绘技术, 对土地的变更、土地调查和动态进行相关监 测。在地籍测绘中, 动态遥感监测技术是对土地利用率和相关调查资料, 通过数字和图形等难识别对象为基础, 利用计算机相关技术, 对难识别的 信息进行处理, 变成可识别的文字和图像, 然后记录相关数据信息, 合理确 定监测周期, 对土地利用变化情况进行全新的监测。

\section{3 结束语}

本文就通过工程测绘技术在地籍测量中的具体应用分析, 结合现代测 绘技术特点与应用考虑因素, 全方位探究地籍测量中测绘技术的具体应用, 以此来深化与加强地籍测量中的硬件设备、测绘技术, 从而降低地籍测量 工作难度。

\section{[参考文献]}

[1]陈春杨.遥感技术在地籍测量中的应用[J].科技展望,2016,26(01):156.

[2]周晓妹. 试论无人机遥感技术在测绘工程测量中的应用 [J]. 居 舍, 2019,(20):196.

[3]张海宾.无人机遥感技术在现代矿山测量中的应用探讨 [J].世界有 色金属,2019,(06):44+46. 